\title{
Algorithm with SVD The Implementation of the Weight Product (WP) Method on the Best Employee Selection
}

\author{
The Decision Support System of the Best Employee Selection Implemented by \\ Weight Product Method at PT. Autogrill Services Indonesia
}

\author{
Komang Redy Winatha ${ }^{1}$, I Nyoman Tri Anindia Putra ${ }^{2}$, Naufal Akbar Ihsan Baedlawi ${ }^{3}$ \\ Informatics Engineering, STMIK STIKOM Indonesia, Denpasar, Bali - Indonesia \\ 1'redywin@stiki-indonesia.ac.id, ${ }^{2}$ trianindiaputra@stiki-indonesia.ac.id, ${ }^{3}$ naufalbaedlawi@gmail.com
}

Accepted 3 June 2021

Approved 16 June 2021

\begin{abstract}
PT. Autogrill Services Indonesia is a private company engaged in the food and beverages selling. There are 8 outlets and 379 employees. To achieve maximum performance within the company environment, PT Autogrill Services Indonesia gives an appreciation to employees in the form of the best rewards every month and year calculated based on certain criteria. PT AutoGrill Services Indonesia needs to have a decision support system to simplify the decision-making process. To meet these needs, a web-based decision support system for selecting the best employees was designed using the weight product (WP) method at PT Autogrill Services Indonesia. The design stage includes needs analysis, context diagrams, data flow diagrams, and designing database tables. This system is web-based, using the programming language PHP and MySQL as database storage. The main features contained in this system include processing user data, outlets, employees, criteria, periods, alternatives, scores, and the calculation of monthly and annual winners. Based on the test results, all system functionality components can run well and by expectations.
\end{abstract}

Index Terms- DSS, Decision, Reward, Weight Product

\section{INTRODUCTION}

Employees are one of the main assets for a company. The existence of employees plays an important role either in the implementation or operations in order to achieve business targets[1]. Therefore, companies should always maintain and improve employee performance by means of training, establishing the solid work team, career paths and fulfillment of employee rights and provide rewards or awards for superior employees. Reward is one of the strategies ran by organization or company to motivate its human resources to make more contributions to the company [2]. This is reinforced by the statement by Mangkunegara [3] formulates that performance belongs to inseparable two things namely ability and motivation. The point is in order to achieve optimal performance quality, it takes not only about the ability, but also employee's motivation. Why? Because, if the company has quality resources, it can directly reach the predetermined target. Giving rewards for employees can be a very important factor because it can motivate employees to work harder and improve performance [4]. So far, most companies have given rewards to superior employees to maintain the best performance of employees, including those carried out by foreign private companies namely PT. Autogrill Services Indonesia.

PT. Autogrill Services Indonesia is a private company engaged in the hospitality sector and food and beverages selling, which is a branch of HMSHost International, headquartered in the Netherlands. PT. Autogrill Services Indonesia located at Ngurah Rai International Airport and has 379 employees as of 23 January 2020 consisting of 50 employees of back office management and 8 outlets/restaurants, which divided into: 37 employees of The Coffee Club Departure, 31 employees of Two Dragons, 58 employees of Two Tigers, 25 employees of La Place Landside, 97 employees of La Place Airside, 60 employees of House of Beans, 6 employees of Urban Food Market, and 15 employees of The Coffee Club Arrival. In order to give appreciation to superior employees, each outlet every month gives awards to the best employees (employee of the month). Winners from each monthly outlet will then be contested again to determine the best employee of the year.

The results of interviews and observations with managers and outlet leaders obtained information that the determination of the best employees so far is still subjective based on the manager's personal assessment and then stored them all in the manager's notebook. The limited capabilities possessed by human resources in this case pointed out on decision making, it became a problem when determining who will be the best employees because there are criteria and alternatives that must be counted. Then, there is no system which 
expected to manage criteria data and calculations in order to produce the best employee information, so that the employees who do not fulfil the requirement can possibly win to be the best employee and might raise the high intense of toxic work culture among the employees, instead of having difficulty of analysing the employees performance data review within year to year.

Based on the explanation above which have been described previously, a computerized decision support system (DSS) is needed in order to determine the best monthly and annual employees according to predetermined criteria and requirement. This system can be a tool to assist the companies in making decisions. DSS is a form of computer-based information system specifically developed to support problem solving [5]. DSS can also be interpreted as a computerized information system provides interactive support for business people during the decisionmaking process [6]. Another definition explains that DSS is a computer-based system that utilizes certain data and models to help on decision making and problem solving [7]. The aim of The DSS developing is not intended for the final and absolute decision making, but is built to evaluate an opportunity that might be taken through analysis using the available methods. [8].

Weight product is a method used and implemented on a computerized decision support system (DSS). It is a decision-making method with multi-criteria which used to solve the problem [9]. The selection of this method is based on being more efficient, because the time required for the calculation is relatively shorter [10][11] compared to other methods. This method is able to select alternatives and it is also has the advantages in weighting techniques so that it can be called the easiest method to design among other methods [12].

In addition, recent studies have also examined the effectiveness of the weight product (WP) method compared to other methods. Among them are research by Setyawan, Arini \& Akhlis [13], which analyses the comparison of the WP and SAW methods in supporting the decision of the new employee recruitment process. The results showed that the WP method gave more accurate results than the SAW method. The same method was also examined by Purnomo \& Rozi [14] with a different case study, namely the selection of the best graduates. This study uses two test indicators, namely testing based on the speed of access time and testing RSD (Relative Standard Deviation). The results of the test on the speed of access time and RSD testing, the WP method is more recommended because it is more optimal.

Based on the explanation of the problems and support from related studies, a research was conduted entitled "Implementation of the Weight Product (WP) Method in the Selection of the Best Employees". The purpose of this research is to implement the WP method in a web-based computerized system that can help companies, in this case, PT. Autogrill Services Indonesia in selecting the best employees. The implementation of the weight product (WP) method is considered very relevant in case studies of selecting the best employees based on recent studies that also use the same method.

\section{METHOD}

The method used in this research consists of several stages, namely:

\section{A. Data Collection}

Data collection was carried out in two techniques, namely primary data and secondary data. Primary data were obtained through direct observation and interviews with the outlet manager of PT. Autogrill Services Indonesia. While secondary data were obtained through documentation and literature from various media such as: internet, journals, and those related literature books.

\section{B. Research Stage}

The research steps begin with problem identification, criteria selection, weight product computation, database and interface design, system development, and testing (Figure 1).

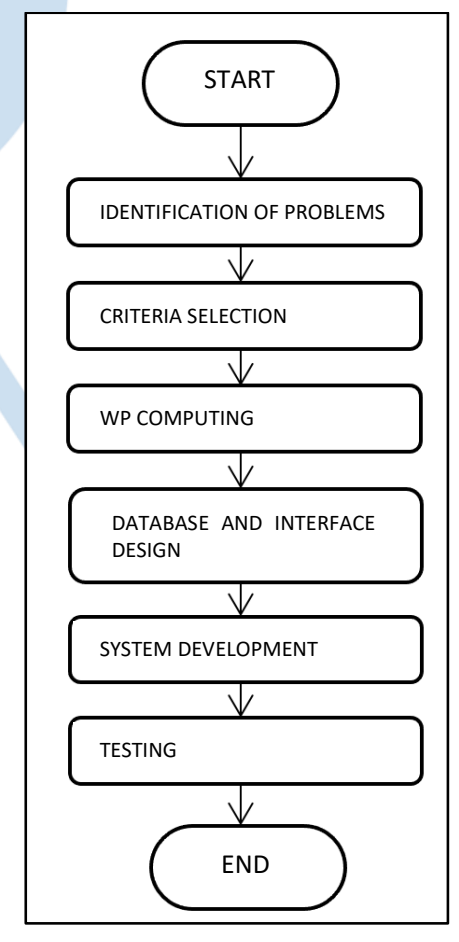

Fugure 1. Research Stage

\section{Determining the Problem and Selection of Criteria}

This research departs from the problem of constrained processes in selecting the best employees. The assessment criteria and the weight of each criterion are shown in Table 1. 
TABLE 1. CRITERIA AND WEIGHT ASSESSMENT

\begin{tabular}{|c|l|c|}
\hline NO. & \multicolumn{1}{|c|}{ KRITERIA } & NILAI BOBOT \\
\hline 1 & NEATNESS & 2 \\
\hline 2 & SKILLS & 3 \\
\hline 3 & ABSENCE & 4 \\
\hline 4 & LATENESS & 4 \\
\hline 5 & COMPLAIN & 5 \\
\hline
\end{tabular}

\section{Weight Product (WP) Computing}

WP computing is carried out through the following stages:

1) Deteremine criteria

The criteria used as a reference in decision making and the nature of the criteria can be seen in Table 2.

\section{TABLE 2. CRITERIA AND ITS TRAIT}

\begin{tabular}{|c|c|}
\hline Criteria & Trait \\
\hline C1 : NEATNESS & Cost \\
\hline NEATNESS STANDARDS ARE & REASON: JUDGING FROM \\
\hline NEEDED AS A CHARACTERISTIC & THE QUANTITY OF \\
\hline OF A COMPANY TO FOSTER & ATTRIBUTES USED OR NOT \\
\hline CONSUMER CONFIDENCE IN THE & ACCORDING TO COMPANY \\
\hline COMPANY. & RULES. \\
\hline C2: SKILL & Cost \\
\hline EMPLOYEE SKILLS ARE VERY & REASON: JUDGED BY THE \\
\hline IMPORTANT IN COMPLETING & QUANTITY OF DAMAGE OR \\
\hline VARIOUS JOBS, BESIDES THAT & WORK \\
\hline EMPLOYEE SKILLS ALSO AFFECT & EQUIPMENT. \\
\hline THE BUSINESS PROCESS & \\
\hline ACTIVITIES THAT ARE BEING & \\
\hline UNDERTAKEN BY A COMPANY. & \\
\hline C3: ABSENCE & Cost \\
\hline THE ABSENCE OF EMPLOYEES IS & REASON: \\
\hline A DISADVANTAGE FOR THE & EMPLOYEES DO NOT COME \\
\hline COMPANY, BECAUSE THE & TO WORK, THE LOWER THE \\
\hline ABSENCE OF ONE OR MORE & PERFORMANCE \\
\hline WORKERS WILL AFFECT THE & APPRAISAL. \\
\hline PERFORMANCE OF THE TEAM IN & \\
\hline GENERAL. & \\
\hline C4 : DELAY & Cost \\
\hline EMPLOYEE TARDINESS IS AN & REASON: THE MORE \\
\hline DISCIPLINARY ACTION THAT & OFTEN EMPLOYEES ARE \\
\hline RESULTS IN DISRUPTION OF & LATE FOR WORK, THE \\
\hline ACTIVITIES WHEN CHANGING & LOWER THE ASSESSMENT \\
\hline WORK SHIFTS & SCORE WILL BE. \\
\hline COMPANY EMPLOYEES. THIS & \\
\hline $\begin{array}{l}\text { CAN CAUSE A LOSS TO YOUR } \\
\text { TEAMMATES. }\end{array}$ & \\
\hline C5 : COMPLAINT & Cost \\
\hline COMPLAINTS & REASON: THE \\
\hline AGAINST EMPLOYEES & COMPLAINTS CUSTOMERS \\
\hline DETRIMENTAL FOR & GIVE TO EMPLOYEES, THE \\
\hline COMPANY. & LOWER THE EMPLOYEE'S \\
\hline
\end{tabular}

\begin{tabular}{|c|c|}
\hline CRITERIA & TRAIT \\
\hline COMPLAINTS & PERFORMANCE \\
\hline WHICH SHOW THAT THE & APPRAISAL. \\
\hline EMPLOYEE CANNOT WORK & \\
\hline PROPERLY ACCORDING TO & \\
\hline SERVICE STANDARDS THAT & \\
\hline EXIST IN THE COMPANY. & \\
\hline
\end{tabular}

2) Weight Normalization

Normalization of weights is calculated by dividing the weight of each criterion by the sum of all the weights of the criteria. Normalization of weights using the equation:

$$
W j=\frac{W}{\Sigma W j}
$$

3) Determining the value of the vector $S$

The value of the vector $S$, is calculated using the following equation:

$$
S i=\prod_{j=1}^{n} X_{i j}^{W j}
$$

4) Determining the value of vektor $V$

The vector value to be used calculates the preference (Vi) for ranking. Here is the equation:

$$
V i=\frac{\Pi_{j=1}^{n} X i j^{w j}}{\Pi_{j=1}^{n} X j^{w j}}
$$

5) Ranking the vector values $V$

The next step is to rank the value of Vi from each alternative. The alternative with the highest $\mathrm{Vi}$ value is the best alternative in supporting the decision.

\section{E. Database and Interface Design}

In designing the table structure, this decision support system consists of: tb_alternatif, tb_pemenang, tb_vector, tb_karyawan, tb_outlet, tb_normalisasi_bobot, tb_perhitungan, tb_kriteria, tb_user, tb_temp_skor, tb_skor, dan. The relationship between tables is described as follows:

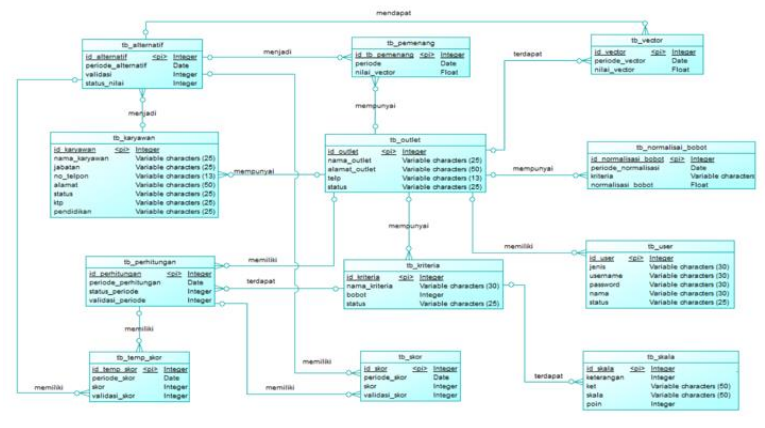

Figure 2. Conceptual Data Model

The system interface consists of the main page, login page, profile page, outlet manager page, 
alternative data page, criteria data page, calculation process page, monthly winner list page, annual winner list page, outlet data page and user data page. The designed interface will display information that can be accessed by outlet managers, operational managers and employees of PT. Autogrill Services Indonesia.

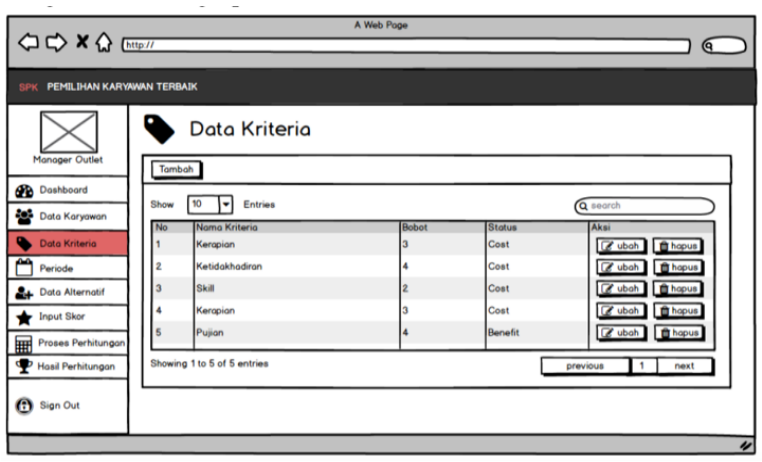

Figure 3. Interface Design

\section{F. Testing}

Testing this decision support system using the black box testing method. This method is used to evaluate software without having to pay attention to details and only checks the output value based on the input value [17]. Blackbox testing is carried out to find several errors, namely: (1) there are missing or even incorrect functions; (2) interface design errors; (3) errors in the data structure or database; (4) faults in terms of performance; and (5) termination and initialization errors [18].

\section{RESULTS AND DISCUSSION}

The initial stage in the study was observation and interviews. Observations were made by coming directly to PT. Autogrill Services Indonesia to observe and find out further the information about problems and solutions to these problems. The next data collection is to conduct an interview with Ahyat Yatendra as the outlet manager of PT. Autogrill Services Indonesia. From all data collection techniques, information is obtained about the best prospective employee data, and what criteria are needed in determining the best prospective employee.

To determine whether or not an employee is eligible to win the best employee competition at PT. Autogrill Services Indonesia then determined 5 criteria that must be met by employees, which later these criteria will be used as a reference for the company in making decisions.

TABLE 3. CRITERIA

\begin{tabular}{|l|l|}
\hline No & \multicolumn{1}{c|}{ CRITERIA } \\
\hline 1 & NEATNESS \\
\hline 2 & SKILLS \\
\hline 3 & ABSENCE \\
\hline 4 & LATENESS \\
\hline 5 & COMPLAINT \\
\hline
\end{tabular}

From the provisions of these criteria, then the weight of each criterion is determined which determines the level of importance.

TABLE 4. WEIGHT CRITERIA

\begin{tabular}{|c|l|c|c|}
\hline No & \multicolumn{1}{|c|}{ Criteria } & Weight VALUE & STATUS \\
\hline 1 & NEATNESS & 2 & COST \\
\hline 2 & SKILLS & 3 & COST \\
\hline 3 & ABSENCE & 4 & COST \\
\hline 4 & LATENESS & 4 & COST \\
\hline 5 & COMPLAINT & 5 & COST \\
\hline
\end{tabular}

After determining the criteria and the weights of these criteria, the next step is to describe the definition and weighting of the rating scale of these criteria.

\section{A. Neatness}

Neatness is needed as a characteristic of a company to foster consumer confidence in the company.

TABLE 5. NINETY ASSESSMENT SCALE

\begin{tabular}{|c|lll|}
\hline SCALE & \multicolumn{3}{|c|}{ DESCRIPTION } \\
\hline 1 & $\begin{array}{l}\text { NOT WEARING ATTRIBUTES ACCORDING TO } \\
\text { COMPANY RULES MORE THAN 8 TIMES }\end{array}$ \\
\hline 2 & $\begin{array}{l}\text { NOT WEARING ATTRIBUTES ACCORDING TO } \\
\text { COMPANY RULES AS MUCH } \\
6-8 \text { TIMES }\end{array}$ \\
\hline 3 & $\begin{array}{l}\text { NOT WEARING ATTRIBUTES ACCORDING TO } \\
\text { COMPANY RULES AS MUCH } \\
3-5 \text { TIMES }\end{array}$ \\
\hline 4 & $\begin{array}{l}\text { NOT WEARING ATTRIBUTES ACCORDING TO } \\
\text { COMPANY RULES AS MUCH } \\
1-2 \text { TIMES }\end{array}$ \\
\hline 5 & $\begin{array}{l}\text { ALWAYS WEAR ATTRIBUTES ACCORDING TO } \\
\text { THE RULES }\end{array}$ \\
\hline
\end{tabular}

B. Skills

Employee skills are an important indicator in completing various jobs, besides that employee skills also affect the business process activities that are being undertaken by a company.

TABLE 6. SKILL ASSESSMENT SCALE

\begin{tabular}{|c|l|}
\hline SCALE & \multicolumn{1}{|c|}{ DESCRIPTION } \\
\hline 1 & DAMAGE OR LOSE EQUIPMENT MORE THAN 8 TIMES \\
\hline 2 & DAMAGE OR LOSE EQUIPMENT 6 -8 TIMES \\
\hline 3 & DAMAGE OR LOSE EQUIPMENT 3 -5 TIMES \\
\hline 4 & DAMAGE OR LOSE EQUIPMENT 1-2 TIMES \\
\hline 5 & $\begin{array}{l}\text { NEVER DAMAGE EQUIPMENT OR REMOVE IT } \\
\text { ALTOGETHER. }\end{array}$ \\
\hline
\end{tabular}

\section{Absence}

Employee absence is a disadvantage for the company because the absence of one or more workers will affect team performance. 


\begin{tabular}{|c|l|}
\hline SCALE & \multicolumn{1}{|c|}{ DESCRIPTION } \\
\hline 1 & ABSENT MORE THAN 8 TIMES \\
\hline 2 & ABSENT 6-8 TIMES \\
\hline 3 & ABSENT 3-5 TIMES \\
\hline 4 & ABSENT 1-5 TIMES \\
\hline 5 & NEVER ABSENT AT ALL \\
\hline
\end{tabular}

\section{Lateness}

Delays can result in disruption of activities when changing work shifts between company employees.

TABLE 8. LATE ASSESSMENT SCALE

\begin{tabular}{|c|l|}
\hline SCALE & \multicolumn{1}{|c|}{ DESCRIPTION } \\
\hline 1 & LATE MORE THAN 8 TIMES \\
\hline 2 & LATE 6 - 8 TIMES \\
\hline 3 & LATE $3-5$ TIMES \\
\hline 4 & LATE $1-2$ TIMES \\
\hline 5 & NEVER LATE AT ALL \\
\hline
\end{tabular}

\section{E. Complaint}

Complaints are things that show that the employee cannot work properly according to service standards that exist in the company.

TABLE 9. COMPLAIN RATING SCALE

\begin{tabular}{|c|l|}
\hline SCALE & \multicolumn{1}{|c|}{ DESCRIPTION } \\
\hline 1 & MORE THAN 8 COMPLAINTS FROM CUSTOMERS \\
\hline 2 & COMPLAINTS 6-8 TIMES FROM CUSTOMERS \\
\hline 3 & COMPLAINTS 3-5 TIMES FROM CUSTOMERS \\
\hline 4 & COMPLAINTS 1-2 TIMES FROM CUSTOMERS \\
\hline 5 & NEVER GOT ANY COMPLAINTS FROM CUSTOMERS \\
\hline
\end{tabular}

\section{Calculation}

Examples of data from employees who will be selected to be the best employees are with 3 employees as follows:

TABLE 10. EMPLOYEE DATA

\begin{tabular}{|l|c|c|c|}
\hline CRITERIA & NAUFAL & DWI & WAWAN \\
\hline NEATNESS & 1 & 2 & 3 \\
\hline SKILLS & 2 & 1 & 4 \\
\hline ABSENCE & 1 & 2 & 3 \\
\hline LATENESS & 1 & 2 & 2 \\
\hline COMPLAINT & 2 & 3 & 1 \\
\hline
\end{tabular}

TABLE 11. EMPLOYEE VALUE DATA WITH SCALE

\begin{tabular}{|l|c|c|c|}
\hline CRITERIA & NAUFAL & DWI & WAWAN \\
\hline NEATNESS & 2 & 2 & 3 \\
\hline SKILLS & 2 & 2 & 3 \\
\hline ABSENCE & 2 & 2 & 3 \\
\hline LATENESS & 2 & 2 & 2 \\
\hline COMPLAINT & 2 & 3 & 2 \\
\hline
\end{tabular}

Score $=\sum$ (criteria weight $x$ rating scale value $)$

TABLE 12. EMPLOYEE FINAL VALUE DATA

\begin{tabular}{|l|c|c|c|}
\hline CRITERIA & NAUFAL & DWI & WAWAN \\
\hline NEATNESS & 4 & 4 & 6 \\
\hline SKILLS & 6 & 6 & 9 \\
\hline ABSENCE & 8 & 8 & 12 \\
\hline LATENESS & 8 & 8 & 8 \\
\hline COMPLAINT & 10 & 15 & 10 \\
\hline
\end{tabular}

The steps for calculating the Weight Product (WP) method from the above case examples are as follows:

1) Find an alternative

In the example calculation method, there are 3 alternative data that will be ranked.

TABLE 13. ALTERNATIVE DATA

\begin{tabular}{|c|l|}
\hline No & EMPLOYEE NAME \\
\hline 1 & NAUFAL \\
\hline 2 & DWI \\
\hline 3 & WAWAN \\
\hline
\end{tabular}

2) Then calculate the normalization of weights, calculate vectors and rank. The previous preference weights are:

$$
\mathrm{W}=(2,3,4,4,5)
$$

$\mathrm{Wj}$ is the $\mathrm{W}$ index to $\mathrm{j}$. So for $\mathrm{W} 1$ is 2 , W2 is 3 and so on.

$\Sigma w j$ is the sum of $W$ is $2+3+4+4+5$. So to fix the W1 weights it becomes:

$$
\begin{aligned}
& W 1=\frac{2}{2+3+4+4+5}=-0.11111 \\
& W 2=\frac{3}{2+3+4+4+5}=-0.16667
\end{aligned}
$$

$$
\begin{aligned}
& W 3=\frac{4}{2+3+4+4+5}=-0.22222 \\
& W 4=\frac{4}{2+3+4+4+5}=-0.22222 \\
& W 5=\frac{5}{2+3+4+4+5}=-0.27778
\end{aligned}
$$

Using the equations described previously, the vector values for each criterion are obtained as follows:

$\mathrm{S} 1=\left(4^{-0.11111}\right)\left(6^{-0.16667}\right)\left(8^{-0.22222}\right)\left(8^{-0.22222}\right)\left(10^{-0.27778}\right)=$ 1.133126 
$\mathrm{S} 2=\left(4^{-0.11111}\right)\left(6^{-0.16667}\right)\left(8^{-0.22222}\right)\left(8^{-0.22222}\right)\left(15^{-0.27778}\right)=$ 1.118945

$\mathrm{S} 3=\left(6^{-0.11111}\right)\left(9^{-0.16667}\right)\left(12^{-0.22222}\right)\left(8^{-0.22222}\right)\left(10^{-0.27778}\right)$ $=1.108697$

Calculating Preference (Vi) for ranking, the results are as follows:

$$
\begin{aligned}
& V 1=\frac{1.133126}{1.133126+1.118954+1.108697}=0.369007 \\
& V 2=\frac{1.118954}{1.133126+1.118954+1.108697}=0.329701 \\
& V 3=\frac{1.108697}{1.133126+1.118954+1.108697}=0.301293
\end{aligned}
$$

From the calculation results above, the highest value is obtained by V1. In other words, V1 is an alternative that can be chosen as the best employee according to the criteria and weights set by the decision maker.

\section{System Implementation}

The main system page can be seen in Figure 4. On this page there are several main menus, namely homepage, company profile and login.
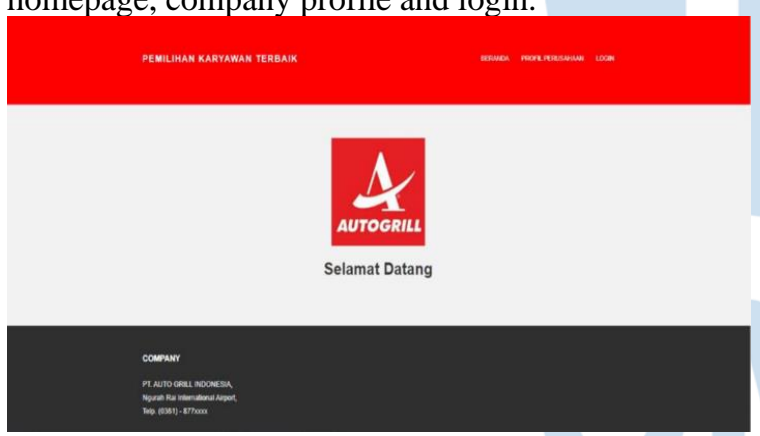

Figure 4. Main Page

\section{Login Page}

User access rights to enter the system are divided into four levels, namely: admin, outlet manager, operations manager, and employees.
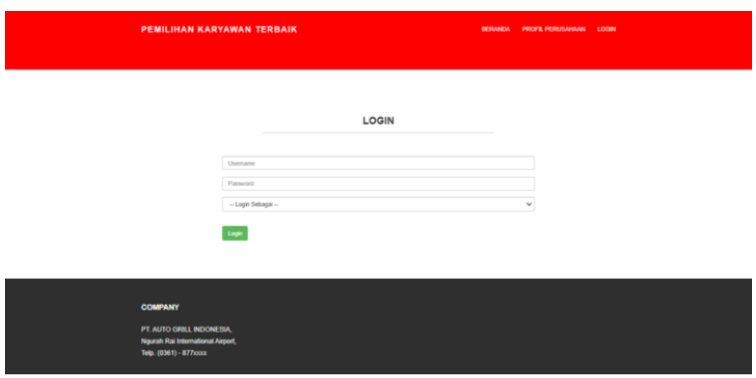

Figure 5. Login page

\section{Admin Dashboard Page}

The admin dashboard page is the main display of admin user access rights when successfully logged into the system. There is information on the number of users who have registered in the system.

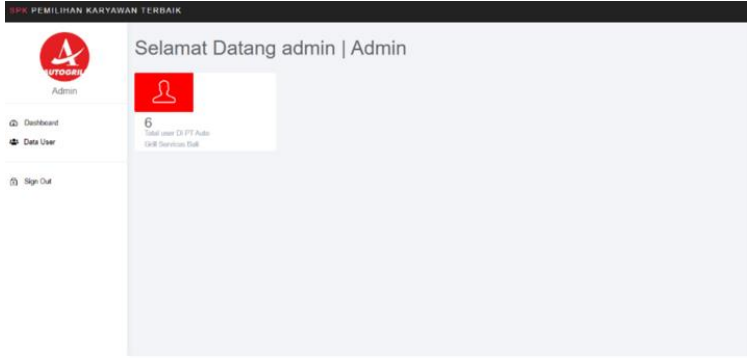

Figure 6. Admin Dashboard Page

\section{User Data Page}

On this page, the admin can view user data information. Admin can also make changes to user data if an error occurs, and search user data.

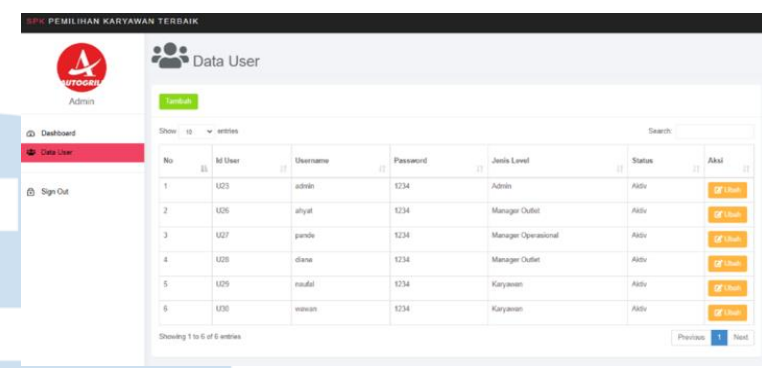

Figure 7. User Data Page

\section{Add User Data Page}

Admin can add new user data, by filling out a form consisting of name, username, password, type, outlet, and status. The condition for adding user data is that all fields cannot be empty. If it is empty, the system will give a warning that there is data that has not been filled in.

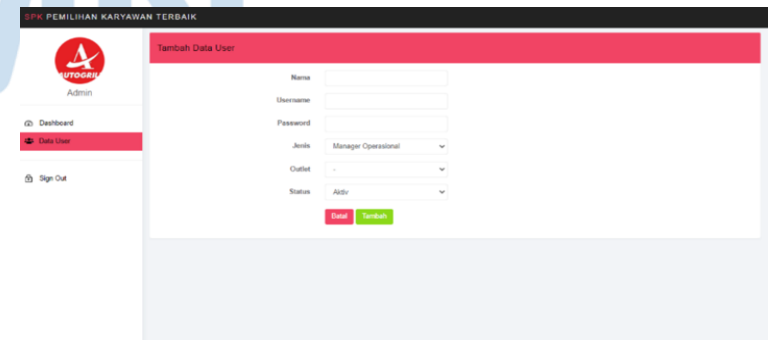

Figure 8. Page Add User Data

\section{Outlet Manager Dashboard page}

This page is the main display of the outlet manager when successfully logged into the system. Managers can view active employee data information that has been registered in the system. On this page there is a dashboard menu, employee data, criteria data, period, alternative data, score data, calculation process and calculation results. 


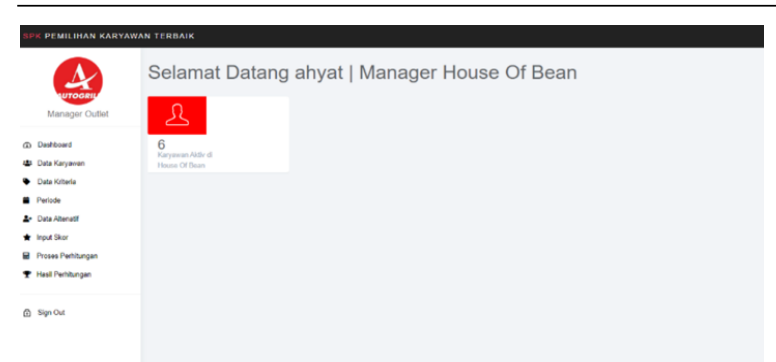

Figure 9. Dashboard Manager Outlet Halaman page

\section{Employee Data Page}

On the employee data page, there is a display of employee data information that has been registered in the system. On this page there are also add, change and search textbox buttons that can be accessed by the outlet manager.

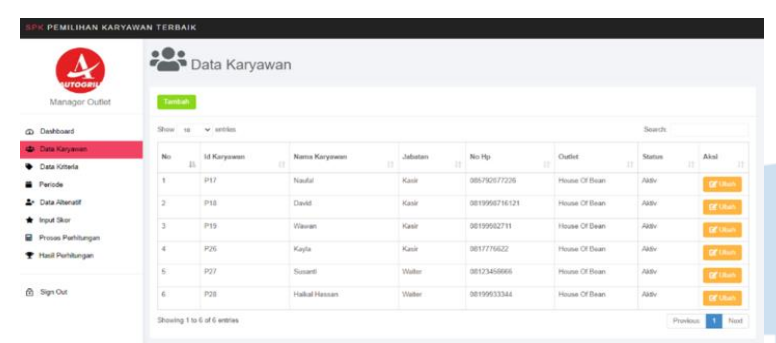

Figure 10. Employee Data Page

\section{Add Employee Data Page}

On the add employee data page, there is a form that must be filled out completely and correctly by the outlet manager to add new employee data to be stored in the system by clicking the add button.

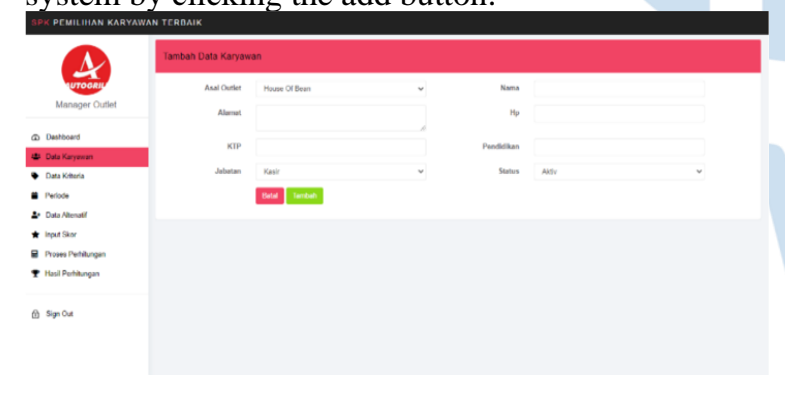

Figure 11. Add Employee Data Page

\section{Change Employee Data Page}

On the change employee data page, there is a form that must be completed with complete and correct data according to the new data that will be changed by the outlet manager then the manager clicks the edit button to save the new data into the system.

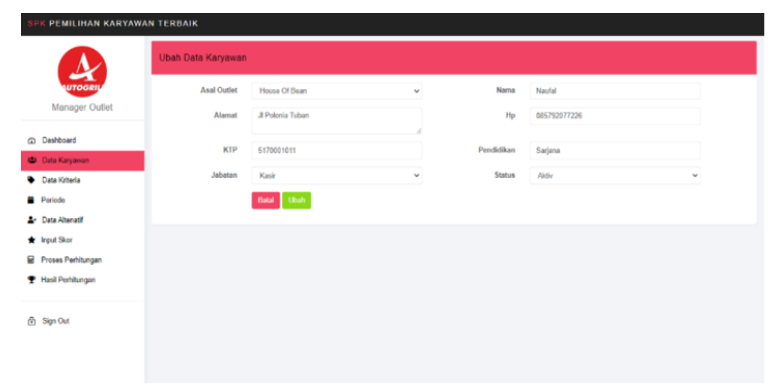

Figure 12. Change Employee Data Page

\section{Criteria Data Page}

On this criteria data page, there is information on criteria data that has been set by the company. On this page there are buttons add, change, delete, and a search textbox.

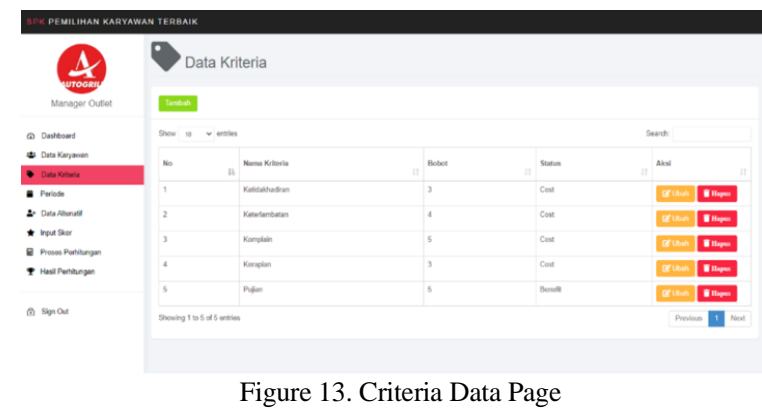

\section{Add Criteria Data Page}

On the add criteria data page, the outlet manager can fill out the form on this page completely and correctly to add new criteria data to the system. The level manager can select the add button to save the criteria data into the system.

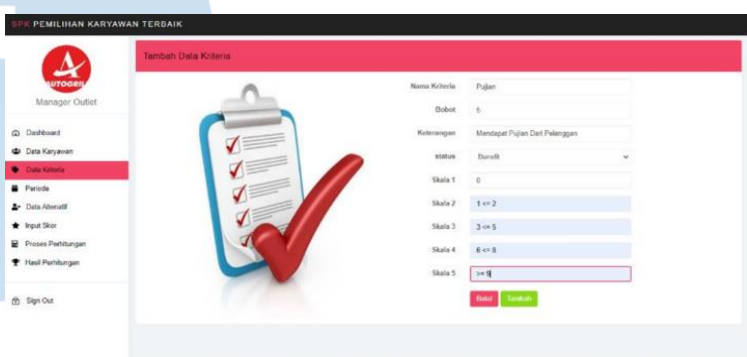

Figure 14. Add Criteria Data page

\section{Period Data Page}

On the data page of this period, there is information that displays the data for the period that is currently running on the system. On this page there is an add button to add period data and a save button to save period data.

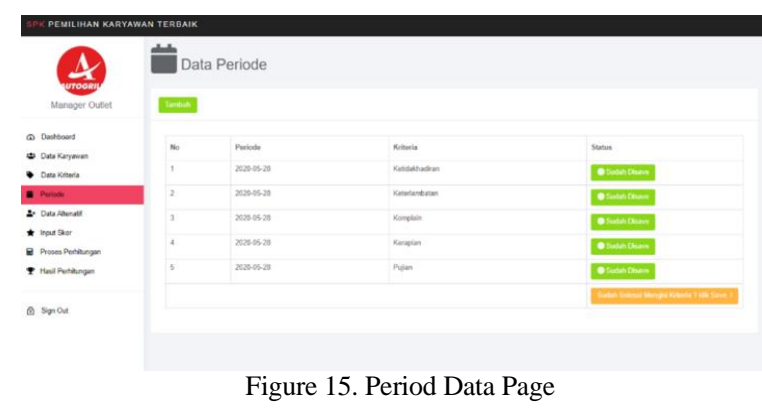

\section{Alternative Data Page}

On the alternative data page, there is information that displays alternative data that has been saved into the system. On this page there are buttons add, delete, validate and textbox search. 


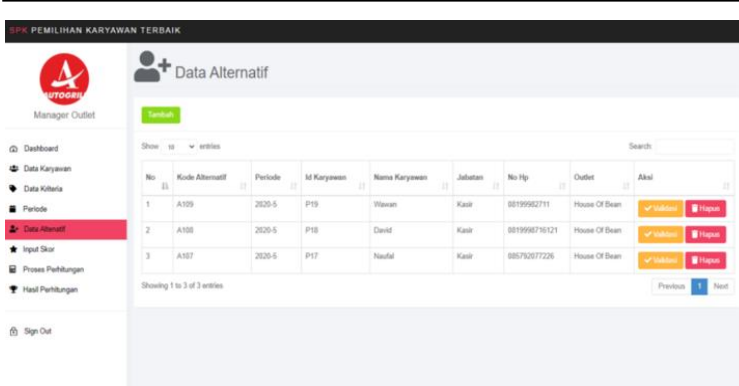

Figure 16. Alternative Data Page

\section{Score Data Page}

On the score data page, there is information that displays the score data that has been stored in the running system. On this page there is an add button, and a search textbox.

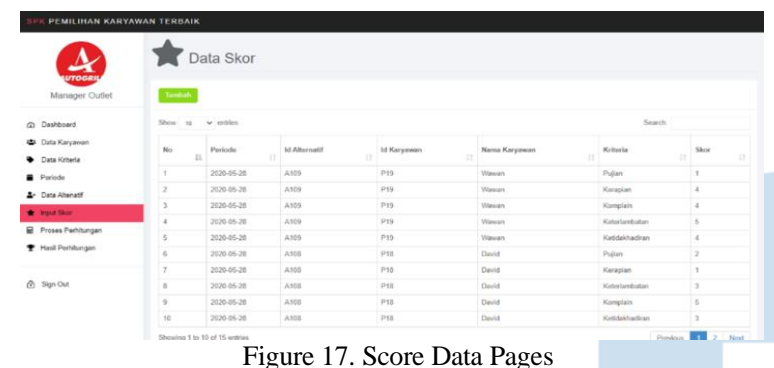

Calculation Process Page

On this page, before performing the calculation process the user is asked to select the calculation period according to the user's wishes. After that, you can proceed by selecting the calculation process button.

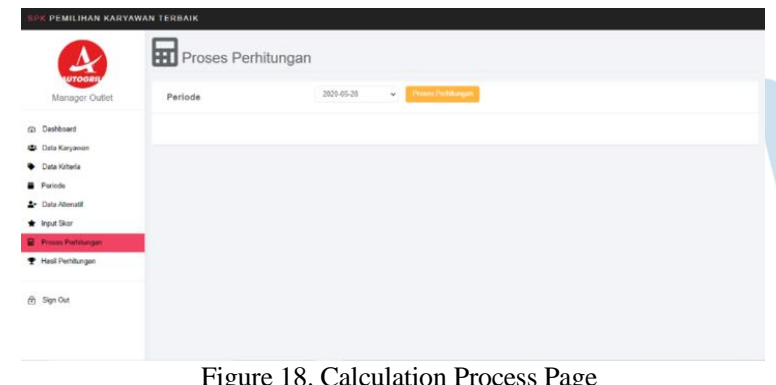

\section{Calculation Results Page}

On the calculation results page, there is information that displays the results of the score calculation which has been completed by the outlet manager. On this page, you can also see information on the calculation results based on the month of the period selected by the outlet manager.

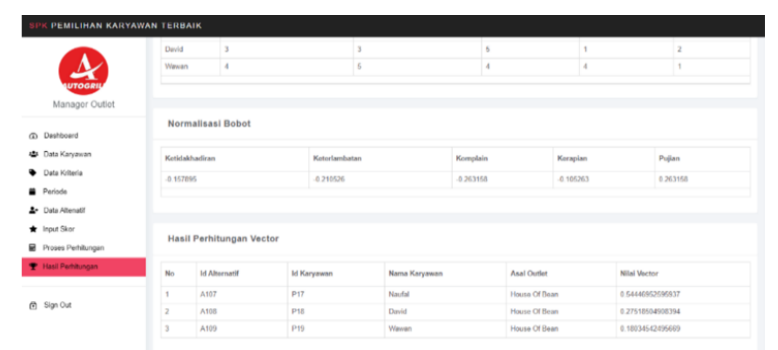

Figure 19. Calculation Results Page

\section{Operations Manager Dashboard Page}

This dashboard page displays data outlets that have been created by the previous operational manager. On this page there is a dashboard menu, data outlets, annual DSS and annual calculation results.

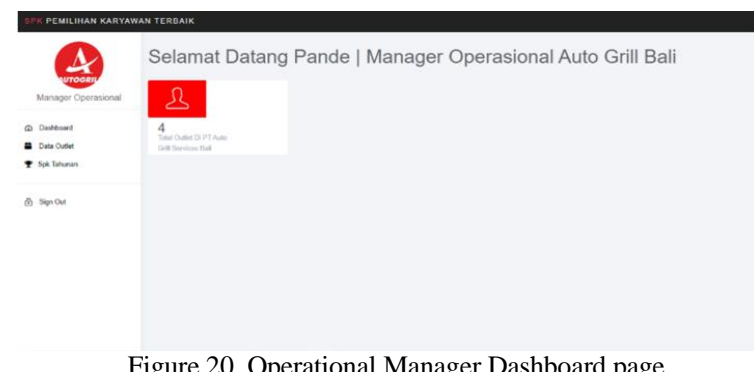

\section{Outlet Data Page}

On the outlet data page, there is information that displays outlet data that has been previously stored by the operational manager. On this page there are add, change, and search textboxes.

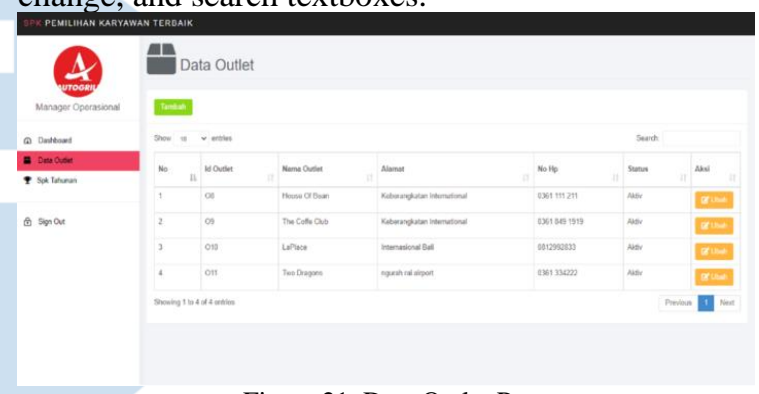

Figure 21. Data Outlet Page

\section{Annual Participant Page}

On the annual participant page, there is information on employee data for the best employee candidates from representatives of each outlet. On this page there is an assessment form that is filled out by the operational manager completely and correctly.

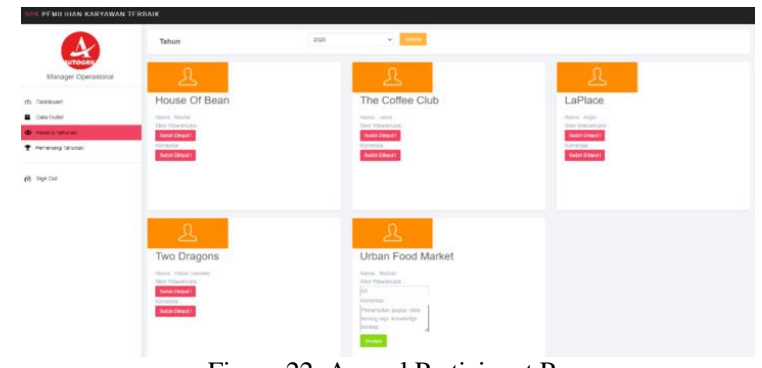

Figure 22. Annual Participant Page

\section{Annual Winner Results Page}

On this page, the operations manager can see the results of the annual winning scores based on the year selected by the operations manager. 


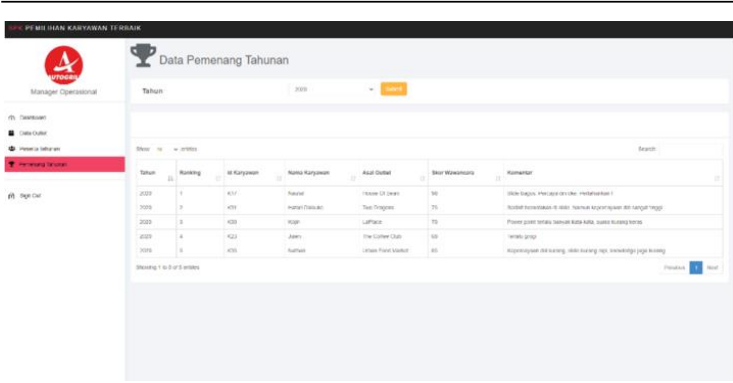

Figure 23. Annual Winner Results Page

\section{Employee Dashboard Page}

On the employee dashboard page there is a dashboard menu, monthly calculation results, and annual calculation results that can be accessed by employees to see the results of the assessment from the outlet manager and operational manager based on the period to be selected.

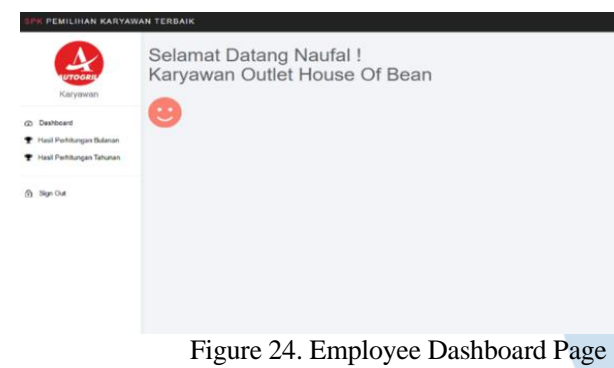

\section{Monthly Calculation Results Page}

On the monthly calculation results page, employees can see the assessment results from the outlet manager based on the selected period, but employees cannot change the results of calculations that have been made by the outlet manager, to prevent data manipulation.

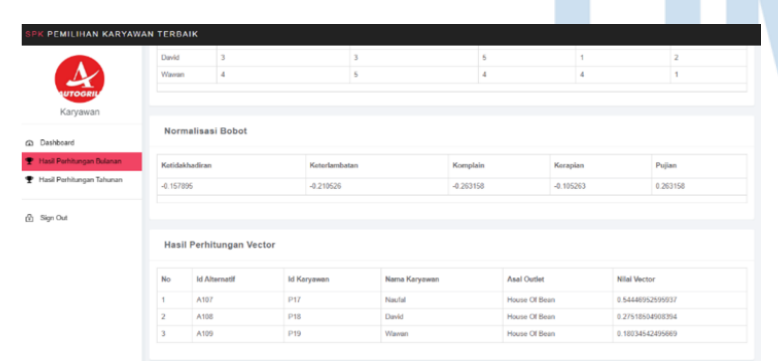

Figure 25. Monthly Calculation Results Page

\section{Annual Calculation Results Page}

On the annual calculation results page, employees can see the results of the assessment from the operational manager based on the selected year, but employees cannot change the results of calculations that have been made by the operational manager, to prevent data manipulation.

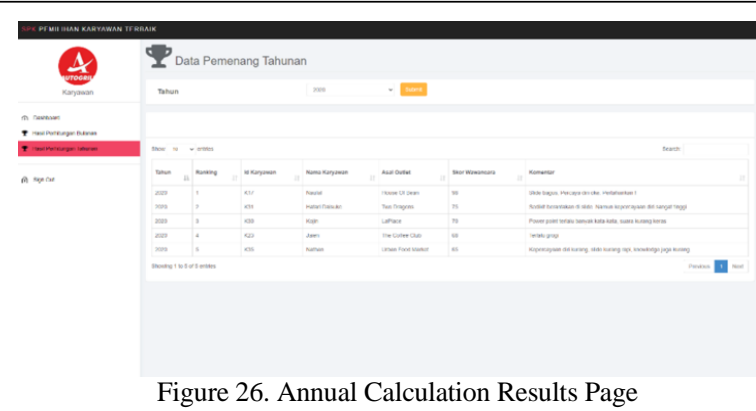

\section{Testing}

The test method used is black box. In this test, all system functionality will be tested based on a predesigned scenario.

\section{TABLE 14. SYSTEM TEST RESULT}

\begin{tabular}{|c|c|c|}
\hline SCENARIO & Test RESUlt & $\begin{array}{c}\text { INFOR } \\
\text { MATIO } \\
\quad N\end{array}$ \\
\hline $\begin{array}{ll}\text { ENTER } & \\
\text { USERNAME AND } \\
\text { PASSWORD } \\
\text { CORRECTLY }\end{array}$ & $\begin{array}{l}\text { THE SYSTEM ACCEPTS LOGIN } \\
\text { ACCESS AND DISPLAYS THE } \\
\text { MESSAGE "LOGIN } \\
\text { SUCCESSFUL" }\end{array}$ & VALID \\
\hline $\begin{array}{l}\text { WRONGLY FILL IN } \\
\text { USERNAME AND } \\
\text { PASSWORD }\end{array}$ & $\begin{array}{l}\text { THE SYSTEM REFUSES LOGIN } \\
\text { ACCESS AND DISPLAYS THE } \\
\text { MESSAGE "LOGIN FAILED" } \\
\text { lat }\end{array}$ & VALID \\
\hline $\begin{array}{l}\text { EMPTY ONE OF } \\
\text { THE TEXT-FIELDS } \\
\text { ON THE ADD } \\
\text { USER FORM }\end{array}$ & 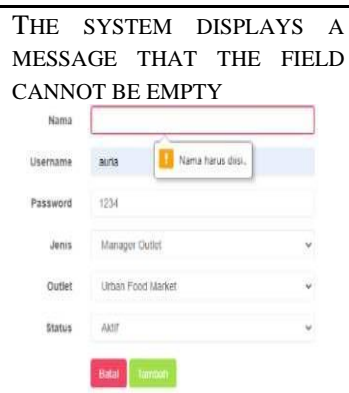 & VALID \\
\hline $\begin{array}{lr}\text { FILL IN ALL TEXT- } \\
\text { FIELDS ON THE } \\
\text { FORM } & \text { ADD } \\
\text { POSITION DATA }\end{array}$ & $\begin{array}{l}\text { THE SYSTEM DISPLAYS A } \\
\text { MESSAGE THAT THE DATA } \\
\text { WAS SUCCESSFULLY ADDED } \\
\text { BERHASIL } \\
\end{array}$ & VALID \\
\hline $\begin{array}{lr}\text { FILL IN } & \text { THE } \\
\text { FORM } & \text { TO } \\
\text { CHANGE } & \text { USER } \\
\text { DATA } & \\
\text { CORRECTLY } & \end{array}$ & \begin{tabular}{lll} 
THE & SYSTEM & DISPLAYS A \\
MESSAGE & THAT & THE DATA \\
WAS & SUCCESSFULLY \\
CHANGED & \multicolumn{2}{l}{}
\end{tabular} & VALID \\
\hline
\end{tabular}


ISSN 2085-4552

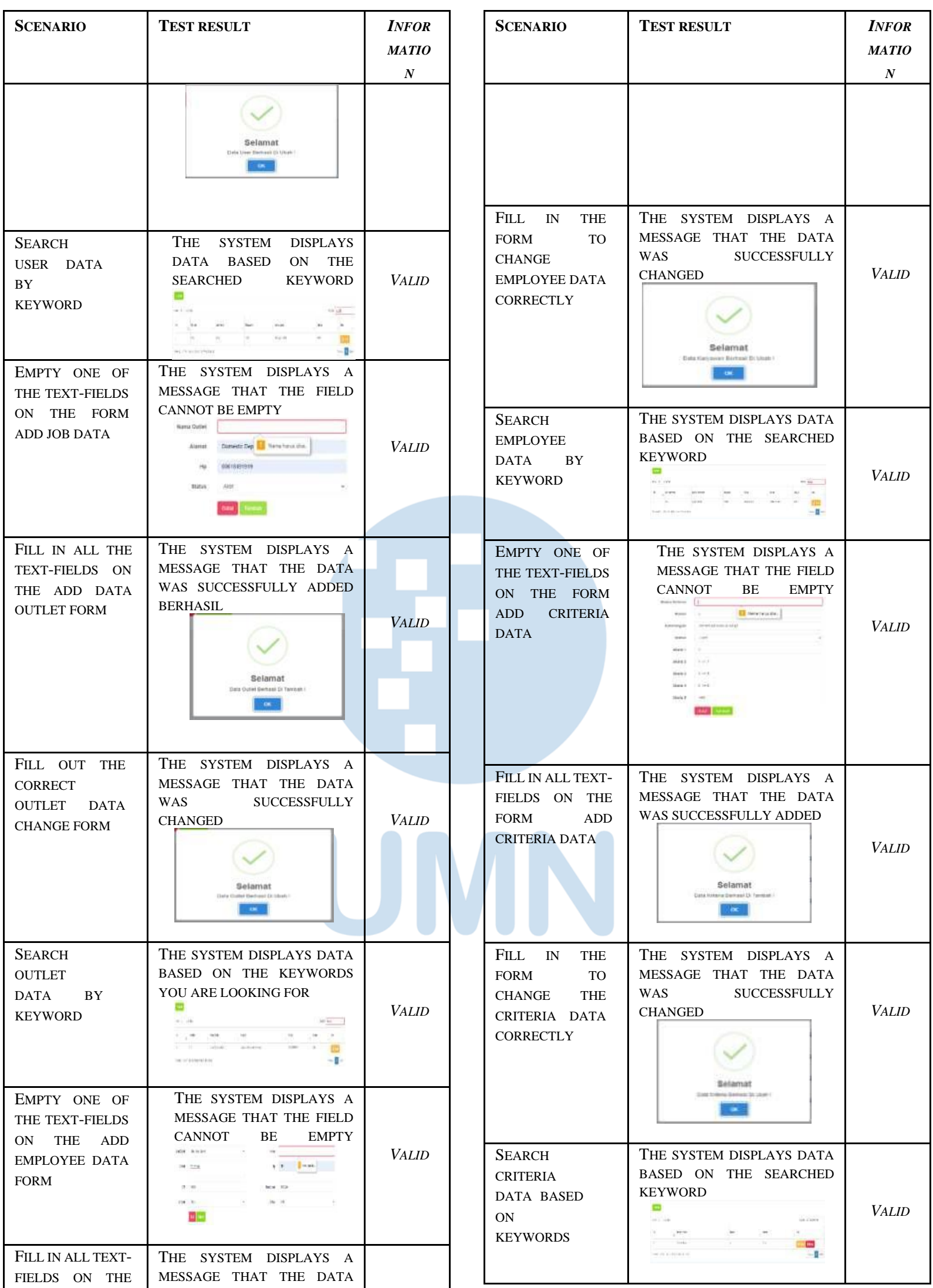

\begin{tabular}{lll|l} 
FIELDS & ON & THE & MESSAGE THAT THE DATA \\
FORM & ADD & WAS SUCCESSFULLY ADDED
\end{tabular}

EMPLOYEE DATA BERHASIL

FORM

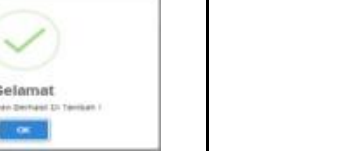


ISSN 2085-4552

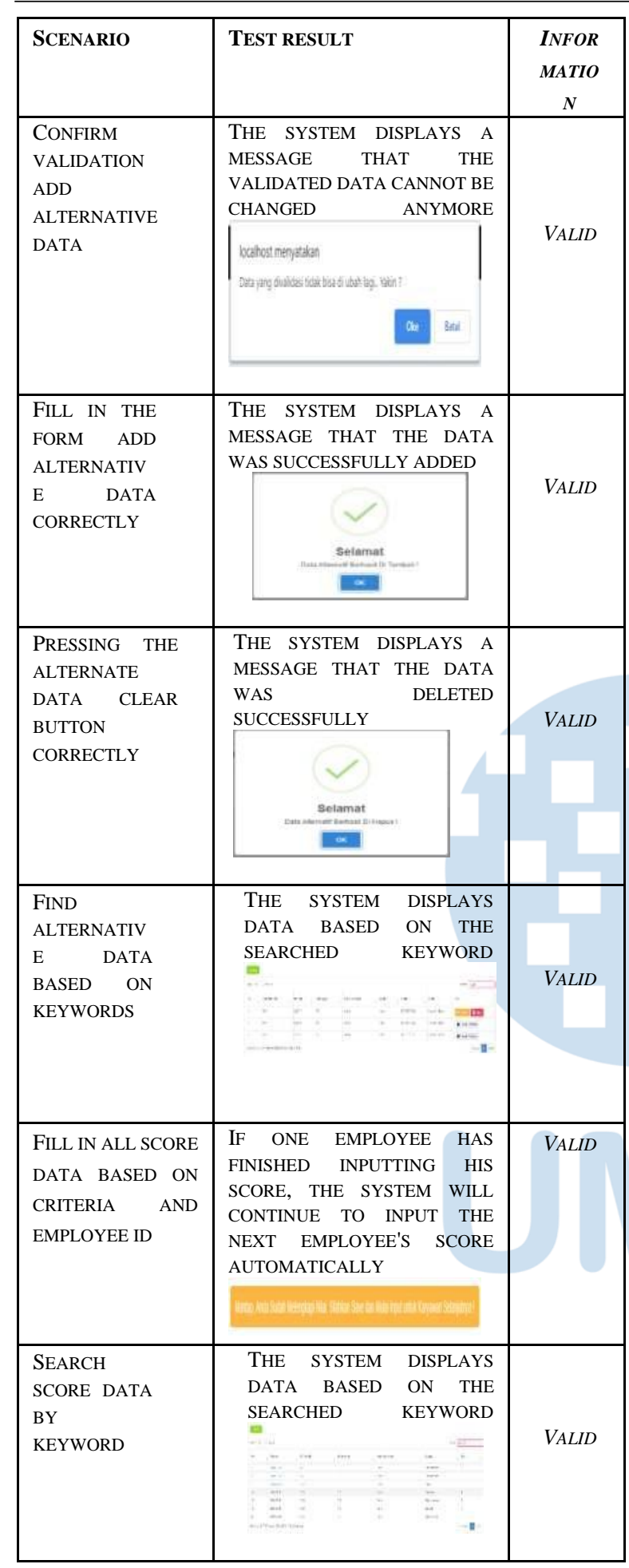

Based on the test results, all system functionality can run well and in accordance with the design results.

\section{IV.CONCLUSION}

Based on the discussion and analysis of the results of system testing, it can be concluded that, the Implementation of the Weight Product (WP) Method on the Best Employee Selection at PT. Autogrill Services Indonesia has been successfully applied through a series of stages such as data collection, analysis, design, implementation and evaluation in building the system. This system functionality has been running well and the output results are in accordance with the design results.

The suggestions for development in further research include: adding backup and import database features on a regular basis as well as adding features for managers so that managers can input daily log data into the system.

\section{REFERENCES}

[1] W. Bangun, Manajemen Sumber Daya Manusia. Jakarta: Penerbit Erlangga, 2012.

[2] P. P. A. P. Indah, P. I. Rahmawati, and N. D. Andiani, "Pengaruh Sistem Penghargaan (Reward) Terhadap Kinerja Trainee Di Hotel Holiday Inn Resort Baruna Bali," J. Manaj. Perhotelan dan Pariwisata, vol. 2, no. 1, pp. 41-54, 2019.

[3] A. A. A. P. Mangkunegara, Evaluasi Kinerja SDM. Tiga Serangkai, 2005.

[4] F. A. Prasasti, M. P. Hutagaol, and M. J. Affandi, "Pengaruh Penilaian Kinerja Terhadap Kinerja Karyawan Bagian Pemasaran Melalui Faktor Pendorong Motivasi (Studi Kasus: Bank Xyz Kcu Bekasi)," J. Apl. Bisnis dan Manaj., vol. 2, no. 3, pp. 248-257, 2016.

[5] E. Turban, J. E. Aronson, and T.-P. Liang, Decision support systems and intelligent systems (sistem pendukung keputusan dan sistem cerdas). Andi Offset, 2005.

[6] M. Rusli, S. Arifin, and A. Trisnadoli, "Pengembangan Sistem Pendukung Keputusan untuk Penentuan Lokasi Promosi Penerimaan Mahasiswa Baru," J. Komput. Terap., vol. 3, no. 1, pp. 11-18, 2017.

[7] S. Effiyaldi, "Analisis dan Perancangan Sistem Pendukung Keputusan Pemilihan Kendaraan Roda Dua Menggunakan Metode Simple Additive Weighting (SAW) (Studi Kasus : PT. Sinar Sentosa)," J. Manaj. Sist. Inf., vol. 3, no. 1, pp. 911921, 2018.

[8] L. Kristiyanti, A. Sugiharto, and H. A. W, "Sistem Pendukung Keputusan Pemilihan Pengajar Les Privat untuk Siswa Lembaga Bimbingan Belajar dengan Metode AHP (Studi Kasus LBB System Cerdas)," J. Masy. Inform., vol. 4, no. 7, pp. 39-47, 2013.

[9] K. Eliyen and F. S. Efendi, "Implementasi Metode Weighted Product Untuk Penentuan Mustahiq Zakat," InfoTekJar (Jurnal Nas. Inform. dan Teknol. Jaringan), vol. 4, no. 1, pp. 146-150, 2019.

[10] E. Ningsih, Dedih, and Supriyadi, "Sistem Pendukung Keputusan Menentukan Peluang Usaha Makanan yang Tepat Menggunakan Weighted Product (WP) Berbasis Web," ILKOM, vol. 9, no. 3, pp. 244-254, 2017.

[11] S. Susliansyah, R. R. Aria, and S. Susilowati, "Sistem Pemilihan Laptop Terbaik Dengan Menggunakan Metode Weighted Product (Wp)," J. Techno Nusa Mandiri, vol. 16, no. 1, pp. 15-20, 2019.

[12] Basri, "Metode Weighted Product dalam Sistem Pendukung Keputusan Penerimaan Beasiswa Prestasi," J. INSYPRO, vol. 2, no. 1, pp. 1-6, 2017.

[13] A. Setyawan, F. Y. Arini, and I. Akhlis, "Comparative Analysis of Simple Additive Weighting Method and Weighted Product Method to New Employee Recruitment Decision Support System (DSS) at PT. Warta Media Nusantara," Sci. J. Informatics, vol. 4, no. 1, pp. 34-42, 2017.

[14] A. S. Purnomo and A. F. Rozi, "Comparative Analysis Uses Weighted Product (WP) and Simple Additive Weighting (SAW) Methods in the Best Graduation Selection System," Sebatik, vol. 23, no. 1, pp. 44-52, 2019.

[15] E. W. Fridayanthie, N. Khoirurrizky, and T. Santoso, "Sistem Pendukung Keputusan Pemilihan Karyawan Terbaik Menggunakan Metode Weighted Product," Paradig. - J. 
Komput. dan Inform., vol. 22, no. 1, pp. 41-46, 2020.

[16] M. Adnan Farizhi and A. Diana, "Sistem Pendukung Keputusan Pemilihan Karyawan Terbaik Untuk Promosi Jabatan Dengan Metode WP (Weight Product)," Pros. Semin. Nas. Teknoka, vol. 5, no. 2502, pp. 9-18, 2020.

[17] A. A. Arwaz, T. Kusumawijaya, R. Putra, K. Putra, and A Saifudin, "Pengujian Black Box pada Aplikasi Sistem Seleksi Pemenang Tender Menggunakan Teknik Equivalence Partitions," J. Teknol. Sist. Inf. dan Apl., vol. 2, no. 4, p. 130, 2019.

[18] D. Febiharsa, I. M. Sudana, and N. Hudallah, "Uji Fungsionalitas (BlackBox Testing) Sistem Informasi Lembaga Sertifikasi Profesi (SILSP) Batik Dengan AppPerfect Web Test Dan Uji Pengguna," JOINED J., vol. 1, no. 2, pp. 117-126, 2018. 